\title{
On The Process Of Thematic Consolidation Of Legal Terms
}

\author{
${ }^{1}$ Muyassarkhon Bakhriddinova, ${ }^{2}$ Vasila Mamadayupova \\ ${ }^{1}$ Senior teacher, Department of Foreign languages, Tashkent State University of Law, Tashkent, Uzbekistan. \\ E-mail: muyassar1971@tsul.uz \\ ${ }^{2}$ Senior teacher, Department of Foreign languages, Tashkent State University of Law, Tashkent, Uzbekistan.
}

Article History:Received:11 January 2021; Accepted: 27 February 2021; Published online: 5 April 2021

\begin{abstract}
This article is dedicated to the process of thematic consolidation of legal terms. It is evident that terms are commonly utilized in many realms including technology, science, art, literature and law. They have been studied for many years by plenty of scholars since they own primary and secondary meanings. The advancement of cutting-edge technologies has brought about many changes in terminology as well and various terms have appeared in every field. Indeed, law is a very broad area with its differently used words, phrases and word combinations. Nowadays, new terms have also been created in this sphere and they have to be learnt very thoroughly. Presently, lots of presidential decrees and rules have been enacted in a bid to develop law system; therefore, studying legal terms is a must for every linguist working in this field. As W.Shuy stated the main duty of linguists is to help untangle the language confusion (p. 12). Hence, we attempted to present some peculiarities of legal words and differences in their usage.
\end{abstract}

Key words: clauses, monosemantic, synonyms, antonyms, terminology, lexemes, lexicology, pedagogical terminology, lexical layers, legal terms, legislation, negative emotional connotation

\section{Introduction}

One-word clauses and combinations, indicating the exact names of concepts related to science, technology, agriculture, art and literature are called terms.

A word has many meanings, and it can have a primary and secondary meaning. The term does not have this feature. The term is a word, but it differs from ordinary words in the accuracy of its meaning and in its uniqueness. The term is used in a specific special field of science and in the speech of its representatives. For example, terms such as crime, punishment, trial, accused, aggression, recidivism, genocide, terrorism, custody, the Senate, speaker are found only in jurisprudence.

The set of terms and the area that studies the terms is called terminology. The term originates from the Latin word terminus (limit, border).

The vocabulary of the language of law consists mainly of terms, but in order to express and form legal concepts, some norms of such a language process are faced with certain requirements. This is due to the specifics of the term.

The term performs a nominative function - its meaning is equal to a concept within the framework of the norms of a literary language. Since the term is monosemantic in the terminological system, its meaning is equivalent to the concept. That means, terms are special formal unified words that express the same meaning as a word. A single word with multiple meanings represents several concepts.

The term expresses clear, concrete concepts and is devoid of emotional meanings. The meaning of the word can be complex, in which the concept acquires additional meaning and methodological features of the application. Therefore, synonyms meaning the same concept in a language differ from each other in different semantic aspects or application in oral and written speech.

The same word can be a term for several branches of science. However, such words become the name of individual (different) concepts in a particular branch of science. For example, the term "task" in pedagogical terminology means the task assigned to pupils or students, in legal terminology, the term "task" means an important task assigned to an employee working in the law enforcement system. The term "operation" refers to a concept related to surgery in medicine, in legal terminology it refers to the name of an event performed for a purpose or for a specific secret task.

Thus, the terms are different from commonly used words. Words are used in a specific field of science and technology and become terms when used in a limited, narrow sense. To date, the system of terms has already included a number of generally meaningful words expressing the scientific and formal meanings of special fields of science.

In linguistics, especially in lexicology, it is emphasized that lexemes, which are the main lexical unit of a language, exist not in isolation from each other, but in interconnection, in various semantic connections. This principle has led to the creation of different lexical strata. According to a certain pattern, lexical layers are grouped. It is important that, depending on the purpose of the study, one or another principle of grouping terms is used. 


\section{Material and Methods}

Thematic unification of lexical layers and terminological systems. It should be noted that the thematic classification is based, firstly, on the classification of objects and events themselves in real events (extralinguistic factor), and secondly, on the hyponymic relationship of lexemes (interpersonal factor).

Based on the analysis of the collected materials and generalized classifications of terminological groups proposed by M. Kasimova and Sh. Kochimov, it was found that the legal terms of the Uzbek language should be classified as follows:

I. Terms denoting individuals.

This thematic group, in turn, can be divided into smaller subgroups: a) terms denoting persons working in the field of jurisprudence: lawyer, prosecutor, judge, representative, lawyer, shareholder, prosecutor general, guarantor, criminologist, financier, notary, convoy, criminologist, judge, secretary of state; b) terms for punishable persons: accused, bully, aggressor, accused, criminal, immoral, bandit, aggressor, poacher, butler, gangster, drug addict, killer, hijacker, accused, suspect.

II. The terms designating "types of crimes": murder, theft, bribery, rape, robbery, intimidation, slander, extortion and killer.

III. Terms for criminal proceedings: interrogation, investigation, search, sentencing, trial, court, guilty plea, testimony, etc.

IV. The terms denoting the concept of "judicial authorities" are as follows: court (supreme court, local court), prosecutor's office, college of advocates, tribunal, police, etc.

$V$. Terms designating the concept of "place of punishment": cell, prison, guardhouse, colony, zone.

VI. Terms designating the concept of "legal documents": statement, constitution, certificate, power of attorney, indictment, petition, order, will, statute, contract, receipt.

VII. The terms designating the concept of "court decision": a) arrest, deportation, imprisonment, transfer to disciplinary unit, confiscation of property, execution, fine; b) release, parole, sentence replacement, pardon, amnesty.

Jurisprudence consists of several industries, each of which has its own peculiarity and specificity. The meaning of the terms in each area of jurisprudence is invaluable. Legal field terms can also be grouped in relation to the object they represent. These include:

a) terms expressing concepts related to civil matters - individual, legal entity, entrepreneur, creditor, guardianship, trusteeship, property rights, pledge, gift, limited liability company, limited liability company;

b) terms related to the state system and management activities - state law, constitutional law, official power, state court, public associations, public organizations, Oliy Majlis, confederation, ministry, monopolistic activity;

c) terms related to crime - recidivist, fine, imprisonment, drug addiction, murder, terrorism, extortion, looting, espionage, poaching;

d) terms related to economic issues - economic court, procedural inheritance, state duty, economic contract, economic company, commercial law;

e) terms related to housing issues - ownership, lease, municipal fund, share fee, storage certificate (reservation), compensation;

f) terms related to issues of administrative responsibility - administrative responsibility, administrative penalties, environmental impact assessment, confiscation, administrative coercion;

g) terms related to tax issues - income tax, tax object, royalties, subsidies, discounts, declaration, value added tax, invoice, excise tax, land tax, environmental tax;

h) terms related to issues related to labor legislation - labor agreement, collective agreement, collective agreement, right to employment, work book, employer, disciplinary action, labor standards.

\section{Discussion}

In connection with the development of society and language, some legal terms should serve as a new direct symbol of the state, a specific event, thing, subject, reality, etc., therefore they enter into grammatical relations in the language of legislation. In this context, they can be grouped as follows:

1) legal terms for persons associated with the legal field: prosecutor, recidivist, drug addict, killer, spy, thief, extortionist, heir, investigator, judge, lawyer;

2) terms describing the event, the course of events in the legal field: court proceedings, amnesty, coercion, confiscation, search, appeal, imprisonment, release, proceedings, conviction, investigation, interrogation, etc .;

3) legal terms denoting the name of legal documents: order, act, subsidy, certificate, license, sanction, declaration;

4)terms denoting socio-political processes related to law: agreement, referendum, elections, monitoring;

5) terms indicating cases directly related to financial means: fine, tax, duty, pension, alimony, salary, fee, scholarship, allowance, bonus; 
6) terms defining the status and system of punishment: imprisonment, death penalty, colony.

The terms with a negative emotional connotation in the legislation are mainly words that determine the degree of crime: they describe crimes related to the state of an individual, event, incident, process:

- crimes against the person;

- crimes against peace and security;

- economic crimes;

- crimes in the field of ecology;

- crimes against military service procedures, etc.

\section{Results}

In systemic lexicology, the issue of determining the relationship of lexical units in the center of lexicalsemantic groups occupies an important place. It should be noted that the types of semantic connection are different. These include synonymy, antonymy, hyponymy, partonymy, degrees, functionalism, hierarchy.

Therefore, the terms in the legal terminological system have a hyponymic relationship to each other. science.

The definition of thematic groups of legal terms gives a clear idea of the special terminology of any field of reality.

Terms in thematic groups, being interconnected and in different semantic relationships, prove linguistic

The definition of hyponymic (gender) relations of legal terms confirms that the terminology in this area is systemic.

In legal terminology, synonymy has also spread, consisting of two or more terms to express a single concept. This situation complicates the process of exchanging information.

\section{Conclusion}

In legal terminology, polysemy is characterized by abundance. It became clear that to limit polysemy, a thesaurus is needed, which is considered a negative phenomenon.

One of the linguistic realities confirming the interconnection of terms is antonymy. Naturally, there are antonyms in legal terminology. The specificity of jurisprudence requires this.

\section{References}

1. Black, Max (1962). “Metaphor”. In: Artunova, A.D. (ed). Theory of Metaphor, 153-172. Moscow: Progress.

2. Black, Max (1993). "More About Metaphor". In: Ortony, A. (ed). Metaphor and Thought, 19-41. Cambridge: Cambridge University Press.

3. Cienki, Alan (2007). "Frames, Idealized Cognitive Models and Domains". In: Geeraerts, D. (ed). The Oxford handbook of cognitive linguistics, 170-188. Oxford: Oxford University Press.

4. Mousavi, Miangah (2006). "Applications of Corpora in Translation”, Translation Studies, 12, 43-56.

5. Munday, J. (2012). Introducing Translation Studies. New York: Routledge."quote, v.". (2017). OED Online. Oxford University Press. Retrieved http://www.oed.com/view/Entry/156901?redirectedFrom=quote\&

6. Rossini, C. (1999). English as a legal language. The Hague: Kluwer Law International.

7. Sager, J. C. (1990). A practical course in terminology processing. Amsterdam: John Benjamins Publishing.

8. Šarčević, S. (1997). New approach to legal translation. The Hague: Kluwer Law International.

9. Stokes, S. (2012). Artist's Resale Right (Droit de Suite): UK Law and Practice. Builth Wells, United Kingdom: Institute of Art and Law.

10. Tiersma, P. M. (2012). The Oxford handbook of language and law. Oxford [u.a.: Oxford Univ. Press.

11. Baxriddinova, M. R. (2016). Эффективные методы предотвращения конфликтов в Высших учебных заведениях.

12. Rahimovna, B. M. (2020). THE LEXICOGRAPHICAL ASPECTS OF LEGAL TERMS IN GERMAN AND UZBEK LANGUAGES. Oriental Art and Culture, (V).

13. Raximovna, B. M., Farxodovna,. K. D., , . J., Axmedovna, N. \& Ibragimovich, . U. B. (2020) VOCABULARY RETENTION IN COGNITIVE THEORY. Journal of Critical Reviews, 7 (2), 402-404. doi:10.31838/jcr.07.02.78.

14. Shokirovich, T. O., \& Abdijalilovna, Z. D. (2020). Teaching EFL and ESP for Law. Activities and challenges during the covid-19 pandemic in Uzbekistan. Solid State Technology, 63(6), 8318-8325. 
15. Nigorakhon Rakhimovna Ruzibaeva (2021). COGNITIVE LINGUISTICS: BASIC CONCEPTS. Academic research in educational sciences, 2 (1), 438-446.

16. Miraziz, R., \& Oybek, T. (2020). INGLIZ, FRANSUZ VA O'ZBEK SHE'RIYATINI TARJIMA QILISHDA QO'LLANILADIGAN TRANSFORMATSIYALAR. Oriental Art and Culture,(V).

17. Urunov, B. I., Mirgiyazova, M. M., \& Saidova, M. S. (2020). THE PEDAGOGICAL CONDITIONS FOR EFFECTIVE TRAINING LANGUAGE TEACHERS PROFESSIONAL DEVELOPMENT NEW METHODS AND TECHNOLOGIES. Theoretical \& Applied Science, (4), 1017-1019.

18. Mirgiiazova, М. М. (2019). Scientific approaches to teaching foreign languages. Молодой ученый, (47), 37-39.

19. Миргиязова, М. М. (2019). The importance of the formation of discursive competence in the development of oral speech. Молодой ученый, (26), 311-313

20. Ruzibaeva, N. (2019). PECULIARITIES OF THE ANTITHESIS IN THE LITERARY TEXT. European Journal of Research and Reflection in Educational Sciences Vol, 7(11). 